\title{
Dynamic Modeling and Simulation of Reformed methanol Fuel Cell System Using Modelica
}

\author{
Xin Yao Tian ${ }^{1}$ Lin Lin Yang $^{1}$ Rui Gao ${ }^{2}$ \\ ${ }^{1}$ Dalian Institute of Chemical Physics, Chinese Academy of Sciences, Dalian 116000, Liaoning \\ \{tianxinyao, yanglinlin\}@dicp.ac.cn \\ ${ }^{2}$ Modelon K.K. Roppongi 1-10-3-209, Minato ku, Tokyo, 106-0032, Japan \\ rui.gao@modelon.com
}

\begin{abstract}
In this paper, a dynamic model of a reformed methanol fuel cell (RMFC) system is developed. The base fuel cell model used in the modeling work was provided by Modelon K.K., using Modelica language. RMFC is a coupled multi-physics system involving fluid mechanics, heat \& mass transfer, chemical \& electrochemical reaction. Therefore, the dynamic modeling and simulation analysis of RMFC is valuable for optimizing operation parameters, as well as system controller design. The component model of methanol reformer, methanol catalytic burner and high temperature polymer electrolyte fuel cell are developed and integrated into a system model using Dymola ${ }^{\circledR}$. And the models have been verified by comparison with the experimental data. This model is expected to provide a base for developing the optimal control strategy for the RMFC.
\end{abstract}

Keywords: Reformed methanol fuel cell, High temperature polymer electrolyte fuel cell, Dynamic modeling, Modelica,

\section{Introduction}

Polymer electrolyte membrane fuel cells (PEMFC) are receiving considerable attention, since they convert chemical energy directly into electrical energy with high efficiency and low emission of pollutants. However, PEMFC have a problem with hydrogen storage, transportation and distribution, either under high pressure or on liquid form cooled down to below $-253{ }^{\circ} \mathrm{C}$. One possible solution to this problem is to use a liquid fuel as a hydrogen carrier and reform it into a hydrogen rich gas as it is needed (Justesen K K, 2015). Methanol is a compact form of liquid hydrogen at ambient conditions. On a volume basis, methanol has $40 \%$ more hydrogen than liquid hydrogen, and 140\% more hydrogen than hydrogen compressed at 700 bar (Choon F S, 2018).

A typical reformed methanol fuel cell system consists of three main subsystems: a fuel processor, a high temperature polymer electrolyte membrane (HTPEM), fuel cell power system, and a heat recovery system, As shown in Figure 1.

The methanol reformer in combination with an HTPEM (operating at $120 \sim 180^{\circ} \mathrm{C}$ ) fuel cell leads to simpler system structure compared to the LTPEM (operating at $60 \sim 80{ }^{\circ} \mathrm{C}$ ). Because HTPEM have strong CO resistance up to 30000ppm (10ppm for LTPEM), eliminating $\mathrm{CO}$ cleanup stage in the fuel processor subsystem (Jannellia E, 2005). 
Due to the complex configuration, dynamic modeling and optimization are essential to improve the performance and efficiency of the RMFC system. Most of the fuel cell system dynamic model are developed with Simulink, a block-based environment for multidomain simulation. In this paper, object-oriented equation based language, Modelica, is used for modeling RMFC, which can be easy to modify and reuse. Modelon's commercial Fuel Cell Library (FCL) contains predefined reactors for fuel preprocessing and internal reforming, and predefined stack structures. Besides, FCL provides powerful media model to capture the property of fuel, air and reaction gas. The main contribution of this paper is to create a RMFC model using the Modelon Fuel Cell Library and validate the model with experimental results.

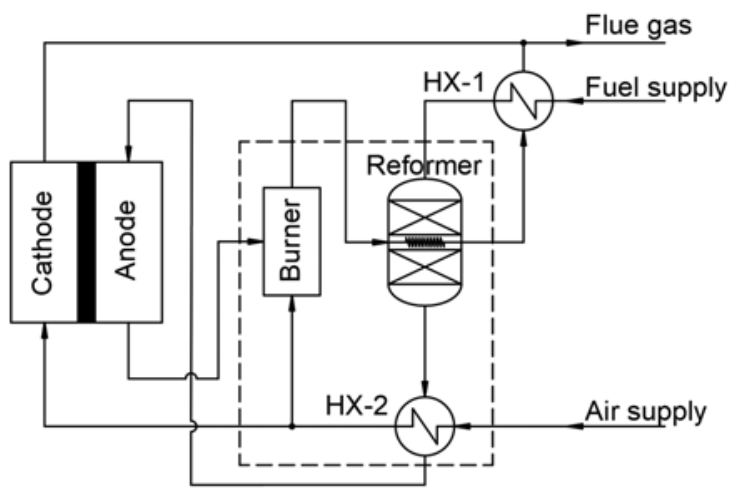

(a)

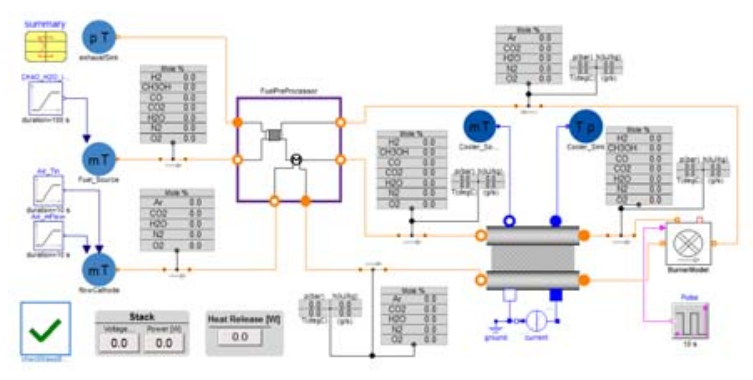

(b)

Figure 1.(a)Reformed methanol fuel cell system process flow chart(b)The fuel cell system model in Dymola

\section{Model}

\subsection{Fuel processor subsystem}

The dashed box in Figure 1 outlines the fuel processor subsystem. A typical fuel processor may consist of a catalytic burner, a reformer and a heat exchanger (HX2).
Catalytic combustion reactions include oxidative combustion of methanol, carbon monoxide, and hydrogen. The burner model has a volume model of air and fuel inlets and air outlets. It also has an energy connector for heat to the environment and a Boolean input for ignition signals. According to the stoichiometric matrix, the fuel-to-fuel ratio is specified and the ignition signal is true to ignite the burner.

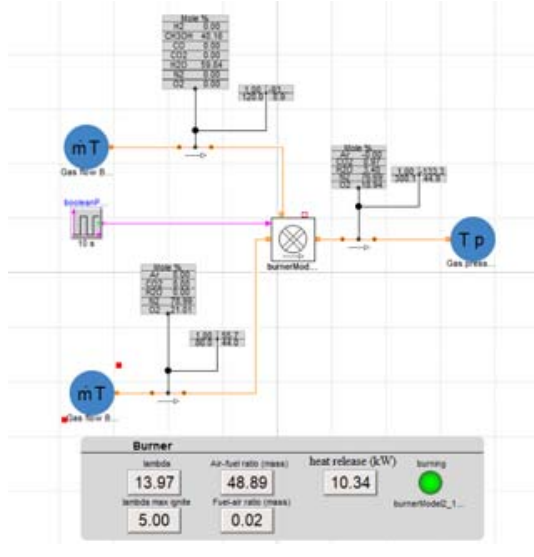

Figure 2.The catalytic burner model

Methanol steam reforming for hydrogen production includes reforming (MSR), cracking (MC) and shift conversion (WGS) (Andreasen S J, 2014). The reformer model is shown in Figure 3. The reformate is cooled to the operating temperature of the stack and enters the anode of the stack as fuel for the fuel cell. As shown in Figure 4.The reaction is as follows:

$$
\begin{array}{lc}
\text { MSR: } & \mathrm{CH}_{3} \mathrm{OH}+\mathrm{H}_{2} \mathrm{O} \rightarrow \mathrm{CO}_{2}+3 \mathrm{H}_{2} \\
\text { MC } & \mathrm{CH}_{3} \mathrm{OH} \rightarrow \mathrm{CO}+2 \mathrm{H}_{2} \\
\text { WGS } & \mathrm{CO}+\mathrm{H}_{2} \mathrm{O} \leftrightarrow \mathrm{CO}_{2}+\mathrm{H}_{2}
\end{array}
$$

The water gas shift reaction (3) is ignored in the model because the CO concentration is very low, less than $1 \mathrm{vol} \%$, at the working temperature $\left(250 \sim 280 \mathrm{C}^{\circ}\right)$ of the reformer. The reforming reactor model in this paper includes methanol fuel gas inlet, reformed gas outlet and catalytic burner tail gas as heat exchange medium.

Reaction kinetic equation (O.P. Klenov, 2015): 


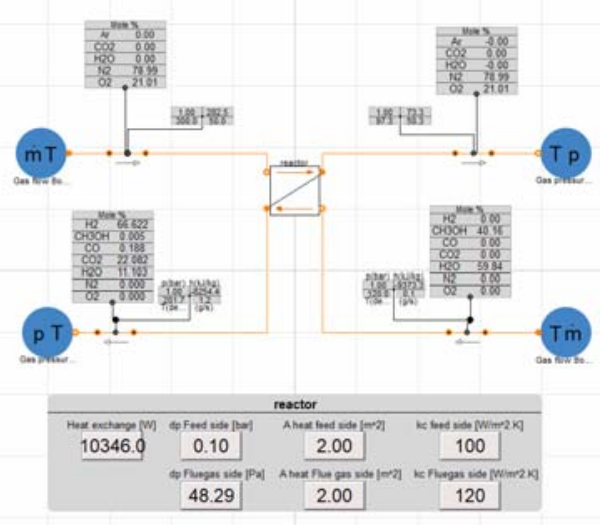

Figure 3.The reformer model

The reformate is cooled to the operating temperature of the stack and enters the anode of the stack as fuel. The fuel processor subsystem As shown in Figure 4.

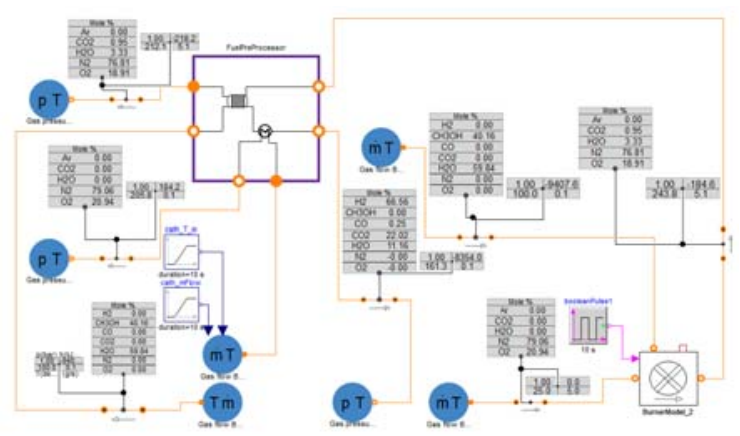

Figure 4.The fuel processor subsystem model

$$
\begin{gathered}
\mathrm{CH}_{3} \mathrm{OH}+\mathrm{H}_{2} \mathrm{O} \stackrel{k_{1}}{\rightarrow} \mathrm{CO}_{2}+3 \mathrm{H}_{2} \\
\mathrm{CH}_{3} \mathrm{OH} \stackrel{k_{2}}{\rightarrow} \mathrm{CO}+2 \mathrm{H}_{2} \\
r_{\mathrm{CH}_{3} \mathrm{OH}}=-k_{1} C_{\mathrm{CH}_{3} \mathrm{OH}}-k_{2} \\
r_{\mathrm{H}_{2} \mathrm{O}}=-k_{1} C_{\mathrm{CH}_{3} \mathrm{OH}} \\
r_{\mathrm{CO}_{2}}=k_{1} C_{\mathrm{CH}_{3} \mathrm{OH}} \\
r_{\mathrm{CO}_{2}}=k_{2} \\
r_{\mathrm{H}_{2}}=3 k_{1} C_{C \mathrm{CH}_{3} \mathrm{OH}}+2 k_{2} \\
k_{1}=\frac{\left[A_{1}+B_{1} \ln \left(\frac{S}{M}\right)\right] e^{\left(\frac{-E_{1}}{R T}\right)}}{P^{D_{1}}} \\
k_{2}=\frac{A_{2} e^{\left(\frac{-E_{2}}{R T}\right)}}{P^{D_{2}}}
\end{gathered}
$$

\subsection{HTPEM fuel cell stack}

Due to the irreversible loss of the HTPEM fuel cell during the reaction, the actual cell potential is less than the equilibrium potential. The irreversible loss of an actual fuel cell is often referred to as a polarized overpotential or overvoltage. There are three main types of polarization that cause irreversible losses: (1) activated polarization; (2) ohmic polarization; (3) concentration polarization. These losses cause the fuel cell voltage to be less than the ideal potential (Daniel, 2016).

The output voltage $V$ cell of a proton exchange membrane fuel cell. It is expressed as follows:

$$
V_{\text {cell }}=E_{\text {Nernst }}-\eta_{\text {act }}-\eta_{o / m}-\eta_{\text {con }}
$$

In the formula, $E_{\text {Nernst }}$ is thermodynamic electromotive force, $\eta$ act is activation overvoltage, $\eta_{\mathrm{ohm}}$ is ohmic overvoltage, and $\eta_{\text {con }}$ is concentration overvoltage.

For $\quad N_{\text {cell }}$ fuel cell units connected in series to form a fuel cell stack, the voltage can be expressed by the formula(14).

$$
V_{\text {stack }}=N_{\text {cell }} \cdot V_{\text {cell }}
$$

(1) Thermodynamic potential

According to the equation of the hydrogen / oxygen fuel cell, the thermodynamic electromotive force can be obtained.

$$
E_{\text {Nernst }}=\frac{\Delta G}{2 F}+\frac{\Delta S}{2 F}\left(T_{\text {stack }}-T_{\text {ref }}\right)
$$

In the formula (15), $\Delta G$ is the change value of Gibbs free energy; $F$ is the Faraday constant (96485C); $\Delta S$ is the change value of entropy; $R$ is the gas constant; $T_{\text {stack }}$ is the temperature of the stack.; $T_{\text {ref }}$ represents the reference temperature. The simplified expression is as follows:

$$
\begin{aligned}
E_{\text {Nernst }}=1.180 & -2.453 \times 10^{-4}\left(T_{\text {stack }}\right. \\
& -323.15)
\end{aligned}
$$

(2) Activation loss

The activation loss mainly manifests when the electrode surface is about to activate the electrochemical reaction, because the electrode cannot overcome the phenomenon of slow rate of activation energy required for the charge transfer process in the electrochemical reaction. Generally, both the anode and the cathode 
generate an activation overpotential, but the reaction rate of the anode is much faster than that of the cathode. Therefore, the activation overpotential is generally determined by the reaction conditions of the cathode. According to the Tafel equation, the activation loss $\eta_{\text {act }}$ in this paper is expressed as follows:

$$
\begin{gathered}
\eta_{\text {act }}=\frac{R T_{\text {stack }}}{\left(2 \alpha_{a} F\right)} \ln \frac{i}{i_{a}^{0}}+\frac{R T_{\text {stack }}}{\left(4 \alpha_{c} F\right)} \ln \frac{i}{i_{c}^{0}} \\
i_{a}^{0}=i_{a_{-} r e f}^{0} \cdot \alpha_{a}\left(\frac{C_{H_{2}}}{C_{H_{2} \text { ref }}}\right)^{\gamma_{a}} \cdot e^{\left(-1400\left(\frac{1}{T_{e}}-\frac{1}{T_{\text {ref } a}}\right)\right)} \\
i_{c}^{0}=i_{c_{-} \text {ref }}^{0} \cdot \alpha_{c}\left(\frac{C_{O_{2}}}{C_{O_{2} \text { ref }}}\right)^{\gamma_{c}} \cdot e^{\left(-7900\left(\frac{1}{T_{e}}-\frac{1}{T_{\text {ref }}}\right)\right)}
\end{gathered}
$$

(3) Ohmic loss

The ohmic resistance is mainly due to the ionic resistance of the proton exchange membrane. The high temperature membrane ohmic loss $\eta_{\mathrm{o} / \mathrm{m}}$ is expressed by the formula (20), estimated using Ohm's law.

$$
\begin{gathered}
R_{\text {ohm }}=0.4025-0.0007 T_{\text {stack }} \\
\eta_{\text {olm }}=i_{\text {stack }} \cdot R_{\text {olm }}
\end{gathered}
$$

\section{(4) Concentration loss}

Mass transfer affects the concentration of hydrogen and oxygen at the surface of electrocatalyst. Poor mass transport leads to a significant concentration reduction of the oxygen and hydrogen within the catalyst layer. It can be shown, by considering the Nernst and Tafel equation, that concentration has an effect on the fuel cell voltage .The concentration overvoltage $\eta_{\text {con }}$ is expressed as formula (21) (25).

$$
\begin{gathered}
\eta_{\text {con }}=\left(-\frac{R T_{\text {stak }}}{\alpha_{a} F} \ln \left(1-\frac{f\left(\lambda_{a}\right) \cdot i}{3000}\right)\right) \\
+\left(-\frac{R T_{\text {stak }}}{\alpha_{c} F} \ln \left(1-\frac{f\left(\lambda_{c}\right) \cdot i}{2000}\right)\right) \\
f\left(\lambda_{a}\right)=-\lambda_{a} \cdot \ln \left(1-\frac{1}{\lambda_{a}}\right) \\
f\left(\lambda_{c}\right)=-\lambda_{c} \cdot \ln \left(1-\frac{1}{\lambda_{c}}\right) \\
\lambda_{a}=\frac{2 F N_{H_{2}}}{i} \\
\lambda_{c}=\frac{4 F N_{O_{2}}}{i}
\end{gathered}
$$

(5) Single cell equivalent model

The circuit is shown in the Figure 5. In the figure, $R_{\text {ohm }}$ is the ohmic loss, and the Voltage $\mathrm{V}$ already includes activation loss and concentration loss. When the demand current changes, the corresponding voltage changes accordingly.

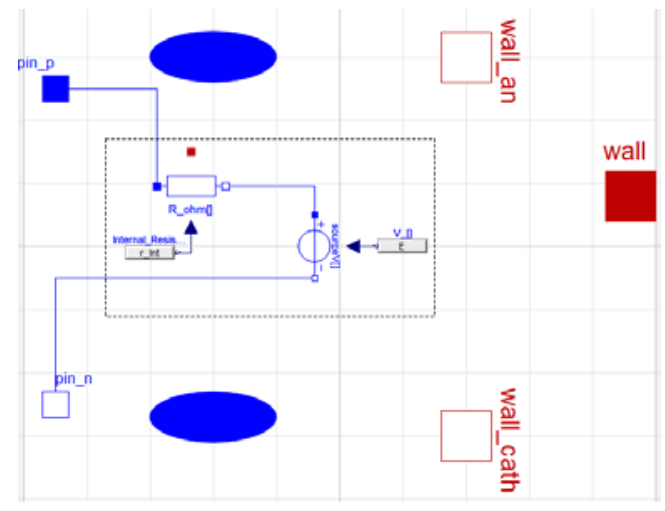

Figure 5.Single cell Model

(6) Stack model

A stack model made of $N_{\text {cell }}$ cells connected in series includes an anode gas flow channel, a cathode gas flow channel, a mass connector, an energy connector, and an electrical component connector. The hydrogen fuel gas required for the anode is provided by the reforming reaction of methanol, not pure hydrogen, so the fuel cell voltage must also consider the voltage drop caused by Carbon monoxide poisoning.

The voltage drop caused by carbon monoxide poisoning can be expressed as:

$$
\begin{aligned}
d V_{\text {poi }}=2.5 \times 10^{4} e^{\left(-0.0424 T_{\text {stack }}\right)} \cdot i+7.48 \\
\times 10^{3} e^{\left(-0.0436 T_{\text {stack }}\right) \cdot i} \\
\cdot \ln \left(\frac{y_{C O}}{y_{H_{2}}}\right)
\end{aligned}
$$

Combined with the above equivalent model, the stack voltage $V_{\text {stack }}$ at steady state can be expressed as:

$$
\begin{gathered}
V_{\text {stack }}=N_{\text {cell }} \cdot\left(E_{\text {Nernst }}-\eta_{\text {act }}-\eta_{\text {olm }}\right. \\
\left.-\eta_{\text {con }}\right)
\end{gathered}
$$

The output power $P_{\text {stack }}$ and consumed power $P_{\text {consumed }}$ of the stack are shown in the following formula (28) (29) The efficiency of the stack $\eta$ is shown in the formula (30).

$$
\begin{gathered}
P_{\text {stack }}=V_{\text {stack }} \cdot i \\
P_{\text {consumed }}=N_{\text {cell }} \cdot\left(\eta_{\text {act }}+\eta_{o / m}+\eta_{\text {con }}\right) \cdot i \\
\eta=\frac{V_{\text {stack }} \cdot i}{N_{\text {cell }} E_{\text {Nernst }} \cdot i}=\frac{V_{\text {cell }}}{E_{\text {Nernst }}}
\end{gathered}
$$




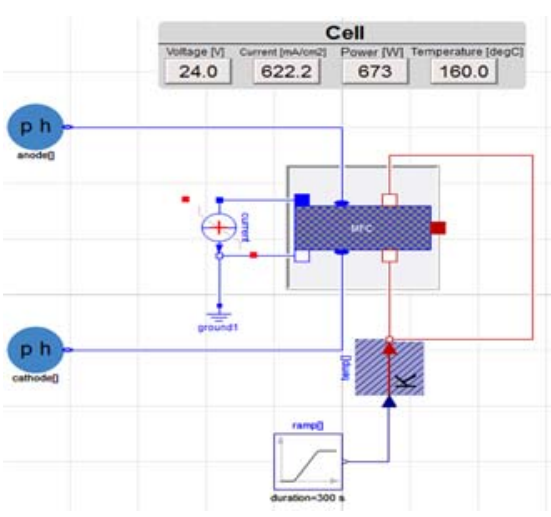

Figure 6. HTPEM stack model

\subsection{Heat recovery subsystem}

As shown in the reformed methanol fuel cell system, the high temperature fuel gas exiting the reformer is used to preheat the air entering the cathode of the stack. As introduced in Section 2.1. This is also conducive to cooling the reforming outlet gas to a temperature suitable for the anode of the stack. The waste heat of the flue gas at the burner outlet is further recovered, and this part of the heat is used for vaporizing methanol.

\section{Results and Discussion}

The remaining parameters of the system model are shown in the following table.

Table 1. Parameters of system model.

\begin{tabular}{|l|c|}
\hline Parameter symbol & Value \\
\hline Active cell area & $45 \mathrm{~cm}^{2}$ \\
\hline Reformer Fuel molar fraction \\
\hline $\mathrm{H}_{2} \mathrm{O}$ & $59.84 \%$ \\
\hline $\mathrm{CH}_{3} \mathrm{OH}$ & $40.16 \%$ \\
\hline Anode Fuel molar fraction \\
\hline $\mathrm{H}_{2}$ & $66.62 \%$ \\
\hline $\mathrm{CO}$ & $0.19 \%$ \\
\hline $\mathrm{CO}_{2}$ & $22.08 \%$ \\
\hline $\mathrm{H}_{2} \mathrm{O}$ & $11.11 \%$ \\
\hline $\mathrm{CH}_{3} \mathrm{OH}$ & $0.0049 \%$ \\
\hline Air oxygen fraction & $21.01 \%$ \\
\hline
\end{tabular}

According to the single cell model built earlier, and the operating parameters in the Table 1, the simulation of the $\mathrm{i}-\mathrm{V}$ curve is performed. Set the temperature of the stack to $120^{\circ} \mathrm{C}, 150^{\circ} \mathrm{C}$, and $180^{\circ} \mathrm{C}$, respectively. The i- $\mathrm{V}$ curves are shown in Figure 7 (a) (b) (c), and the model fit well with the experimental data.

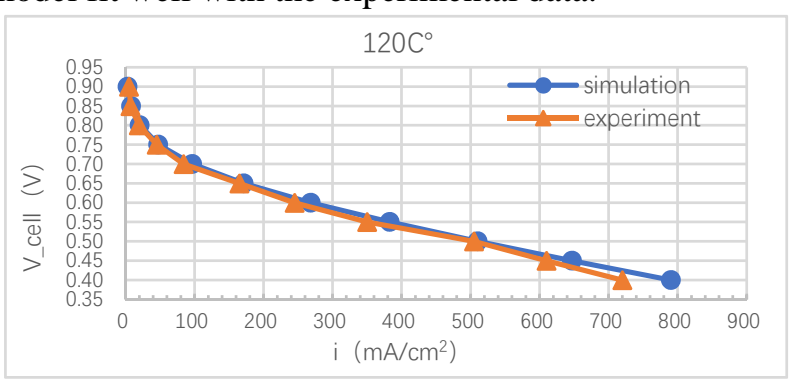

(a)

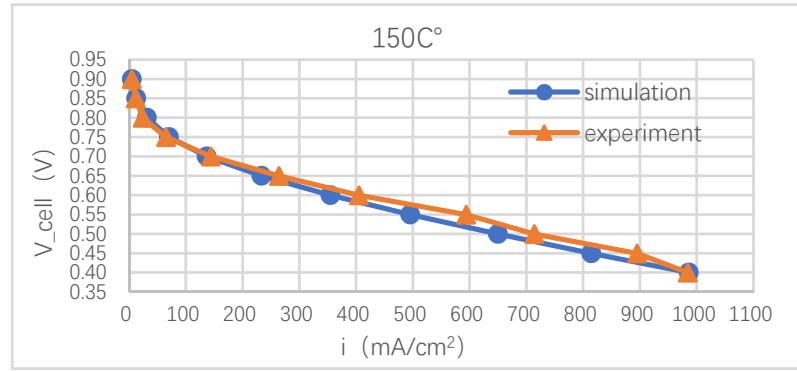

(b)

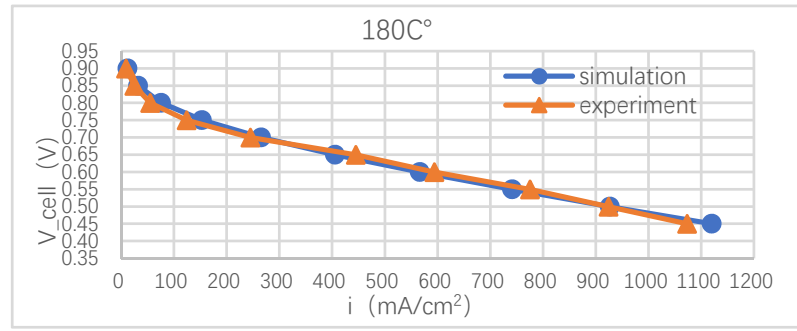

(c)

Figure 7. Comparison between experimental and computational results of HTPEM fuel cell performance

Figure 8 and Figure 9 shows the dynamic response of each component in the reformer and catalytic burner over time. The reformer outlet is the fuel of the anode The reaction quickly reaches its steady state value, and then there is almost no change. This composition is in line with similar simulation results in related literature.

The heat exchanger HX-1 uses residual heat to vaporize a $0.147 \mathrm{~g} / \mathrm{s}$ methanol aqueous solution, recovers about $27 \%$ of flue gas waste heat. And HX-2 preheats cold air from $25^{\circ} \mathrm{C}$ to $120^{\circ} \mathrm{C}$. This part of the heat is provided by the reformer outlet gas. 


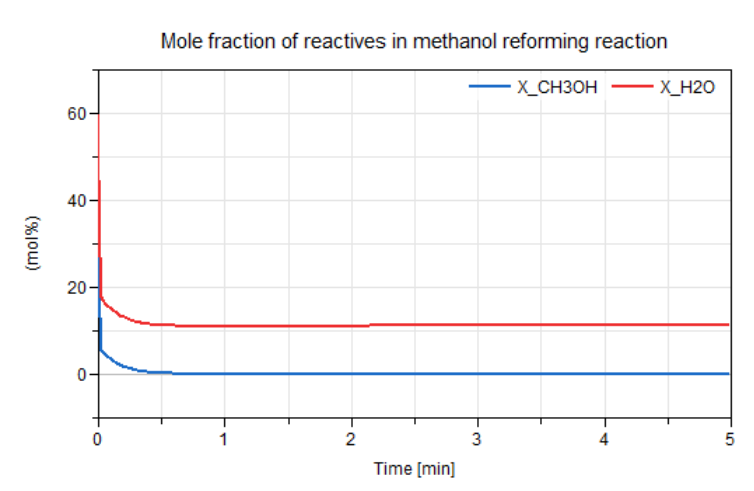

(a)

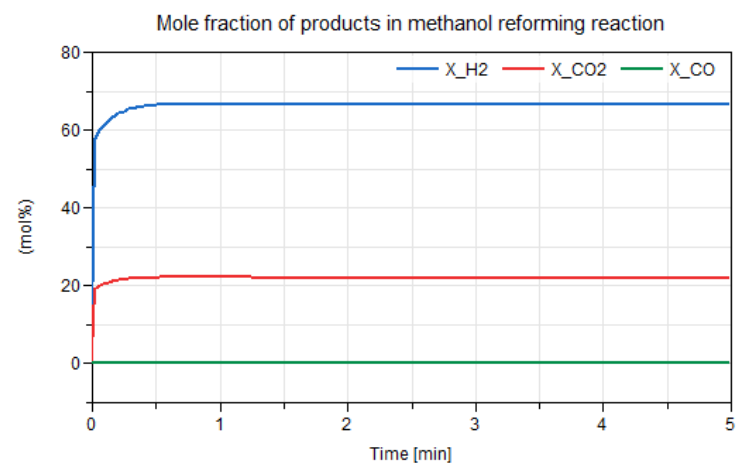

(b)

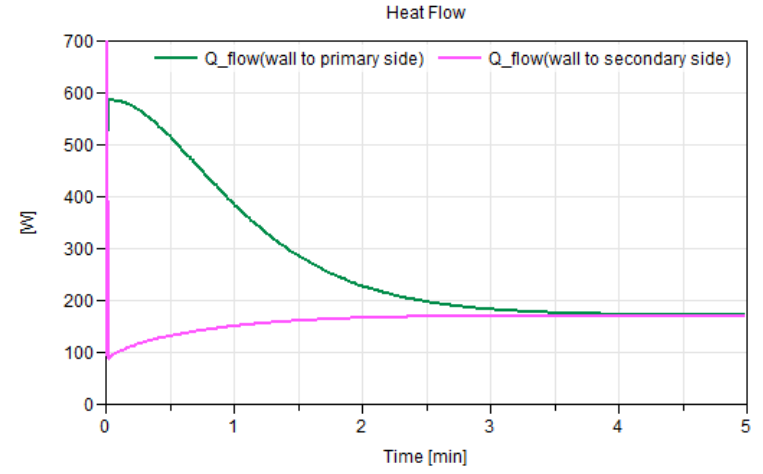

(c)

Figure 8. Simulation results for: (a) methanol,water (b) hydrogen $\mathrm{CO}, \mathrm{CO}_{2}$ content (c) heat required for reforming

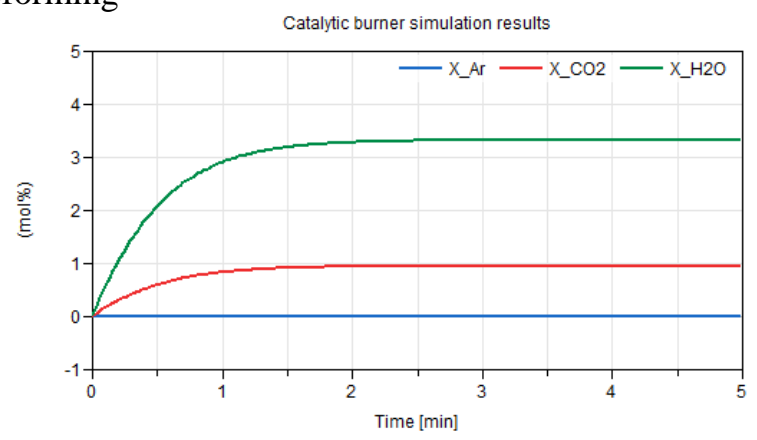

(a)

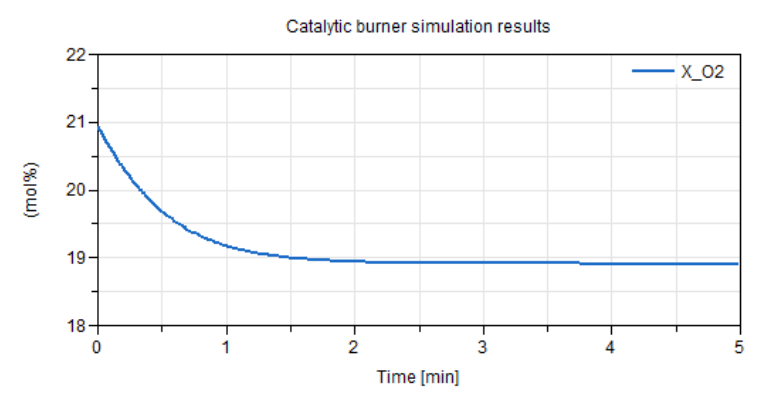

(b)

Figure 9.Catalytic burner simulation results for: (a) $\mathrm{CO}_{2}$, $\mathrm{H}_{2} \mathrm{O}$ content (b) $\mathrm{O}_{2}$ content

\section{Conclusion}

It can be concluded that Dymola and Modelica are very convenient tools for modeling fuel cell systems. Modelica is an equation-based language that offers object-oriented, structural, and multi-domain coupled modeling possibilities and flexibility.

This paper introduces a simple reformed methanol fuel cell system includes a fuel processor subsystem, HTPEM fuel cell stack and heat recovery subsystem. It can provide a basic model for RMFC system analysis and design.

\section{Nomenclature}

\begin{tabular}{ll}
$\mathrm{T}$ & Temperature \\
$\mathrm{P}$ & Pressure \\
$\mathrm{R}$ & Universal gas constant \\
$\mathrm{r}$ & Reaction rate \\
$k_{i}$ & Reaction rate coefficient \\
$A_{i}$ & Parameter in Eq. (12-13) \\
$B_{i}$ & Parameter in Eq. (12) \\
$D_{i}$ & Parameter in Eq. (13) \\
$S$ & Ratio of methanol to water \\
\hline$M$ & Faraday constant \\
$\mathrm{F}$ & Voltage \\
$\mathrm{V}$ & Current density \\
$i$ & Molar fraction \\
$y$ & Stoichiometry \\
$\lambda$ & Charge transfer coefficient \\
$\alpha$ & Pre-exponential factor \\
$\gamma$ &
\end{tabular}




\section{References}

Justesen K K, Andreasen S J, Pasupathi S, et al. Modeling and control of the output current of a Reformed Methanol Fuel Cell system[J]. International Journal of Hydrogen Energy, 2015, 40(46):16521-16531.

Choon Fong Shih, Tao Zhang, Jinghai Li , et al. Powering the Future with Liquid Sunshine[J]. Joule 2, 1925-1949, October 17, 20181927.

Jannellia E, Minutilloa M, Pernab A. Analyzing microcogeneration systems based on LT-PEMFC and HTPEMFC by energy balances. Am Control Conf 2005; 108: 82-91.

Andreasen S J, Ashworth L , Sahlin S , et al. Test of hybrid power system for electrical vehicles using a lithium-ion battery pack and a reformed methanol fuel cell range extender[J]. International Journal of Hydrogen Energy, 2014, 39(4):1856-1863.

O.P. Klenov, L.L. Makarshin, A.G. Gribovskiy, et al. CFD modeling of compact methanol reformer[J]. Chemical Engineering Journal, 2015, 282: S1385894715004817.

Daniel, Ikhu-Omoregbe, Myalelo, et al. Parametric Analysis of a High Temperature PEM Fuel Cell Based Microcogeneration System[J]. International journal of chemical engineering, 2016. 